\title{
ANALISIS BENTUK DAN FUNGSI GERABAH BANYUMULEK LOMBOK BARAT
}

\author{
I Ketut Muka Pendet \\ Jurusan Kriya Seni, Fakultas Seni Rupa dan Desain, \\ Institut Seni Indonesia Denpasar, Indonesia
}

\begin{abstract}
This article analyzes the production of Banyumulek earthenware vessels that recently develops through two different techniques. Some craftsmen preserve the old technique, while the rest begin to employ modern technology or semi traditional system. The later craftsmen attempt to create varying forms of earthenware vessels that are more practical and complemented by decoration presenting solid individual values. This recent development is mostly coined by young craftsmen who have experienced a formal and informal training education. This craftsman group implementing semi traditional technology or semi modern does not totally abandon the old existing models, but continually attempt to develop it in terms of its design and function according to the consumer's demands.
\end{abstract}

Key words: Gerabah Banyumulek, kerajinan, bentuk and fungsi.

Sebagaimana dikemukakan oleh Koentjaraningrat kesenian merupakan salah satu unsur kebudayaan yang universal dan dapat ditemukan pada semua kebudayaan di dunia, baik dalam masyarakat pedesaan yang terpencil maupun dalam masyarakta perkotaan yang besar dan kompleks (1994:2). Gerabah sebagai salah satu bagian dari hasil budaya manusia, dalam sistem sosial budaya masyarakat tradisional memiliki keterkaitan yang erat dengan berbagai aktivitas ataupun upacara tradisional masyarakat pendukungnya. Sudarso Sp (2002) dalam makalahnya "Merevitalisasi Seni Kriya Tradisi Menuju Aspirasi dan Kebutuhan Masyarakat Masa Kini" menyebutkan barang-barang pecah belah (earthenware), cobek, tempayan dan celengan (kitty) tempat menyimpan uang logam, merupakan seni rakyat yaitu seni yang berkembang di desa-desa (dulu) di lingkar istana atau pusatpusat kesenian yang bisa menopang timbulnya budaya agung atau budaya adiluhung. 
Eratnya hubungan baik antara keluarga dan masyarakat, hampir setiap kegiatan sosial budaya dilakukan secara bersamasama. Demikian pula dalam pembuatan gerabah yang di dalamnya terkandung unsur sent terapan perlu dipelajari bukan hanya sebagai seni tradisi yang diturunkan oleh nenek moyang, melainkan juga sebagai upaya untuk memahami keberadaan gerabah dalam tata kehidupan budaya masyarakat. Kerajinan gerabah, anyam-anyaman dari bambu, ukiran kayu dan yang lainnya walaupun dalam bentuknya sederhana merupakan seni komunitas pedesaan yang masih akrab, homogen dan masih berfungsi untuk mengikat solidaritas komunitas (Kayam dalam Sudarso, 2002:2).

Gerabah atau tembikar merupakan peninggalan budaya tradisional yang tergolong sangat tua. Menurut para ahli, berdasarkan penelitian yang dilakukan diketahui bahwa benda-benda tembikar atau gerabah sudah mulai dikenal sejak masa bercocok tanam. Sejalan dengan pendapat tersebut Yardani Yumarta (1981:9) menyebutkan gerabah mulai dikenal manusia sejak zaman neoliticum ketika manusia purba mulai hidup menetap, bercocok tanam dan mengenal api.

Kerajinan gerabah khususnya yang tumbuh dan berkembang di Banyumulek Lombok Barat memiliki nilai spesifik, berbeda dengan gerabah di daerah lain baik bentuk, proses desain, dekorasi serta penyelesaian (finishing) sudah memanfaatkan teknik semi tradisional (modern). Masyarakat pengrajin dalam kemampuannya berkarya dan berkreativitas secara berkesinambungan dengan menciptakan desain baru mengikuti sejera konsumen (pasar). Gustami (2002) dalam makalahnya yang berjudul "Seni Kriya Akar Seni Rupa Indonesia" menyebutkan yang menarik perhatian cabang seni kerajinan (gerabah) dimasing-masing daerah memiliki gaya tersendiri yang dapat melengkapi pesona, daya pikat dan keunggulan komperatif bila dibandingkan dengan cabang seni lainnya.

Faktor bahan, daya kreasi dan kebutuhan sangat menentukan tumbuh kembangnya gerabah Banyumulek. Di samping itu gerabah Banyumulek tetap menampakkan nilai ritual dan ekonomis yang dalam, diilhami oleh karya-karya gerabah penunjang kehidupan sehari-hari, upacara maupun kegiatan rumah tangga. Melalui ketrampilan para pengrajin dalam mengembangkan dan menciptakan bentuk-bentuk baru seperti vas bunga, asbak, tempat lilin, guci air, gentong maupun bentuk lampu taman dengan memadukan unsur-unsur tradisional sebagai ciri khas daerah sangat menentukan pertumbuhan kerajinan gerabah di daerah ini. Peranan disainer dalam usaha mengembangkan dan menciptakan ciri khas daerah sangat 
menentukan, perkembangan gerabah Banyumulek dengan sentuhan nilai modern.

\section{ANALISIS BENTUK DAN FUNGSI}

Bagan 1. Model Perkembangan Gerabah Banyumulek

Budaya Sasak atau budaya masyarakat Banyumulek Lombok Barat memberikan pengaruh terhadap kelangsungan hidup para pengrajin gerabah tradisional. Timbulnya pembaharuan dalam bidang pengolahan bahan, desain dan dekorasi/ornamen sesuai dengan fungsi dan kaidah seni rupa, yang dikordinir oleh instansi terkait seperti Dinas Perindustrian Kabupaten Lombok Barat dan P3SKP Bali. Produksi gerabah Banyumulek tradisional maupun gerabah yang sudah mengalami perkembangan baik bentuk maupun fungsinya akan ditinjau dari sudut, bentuk, dan fungsi Bentuk gerabah Banyumulek secara visual didalamnya menyangkut wujud yang tampil tegak dalam bentuk silinder, bentuk, dalam posisi digantung dan beberapa bentuk dengan penampilan datar serta berbagai unsur seni rupa yang melengkapi sebagai hiasan.

Fungsi gerabah Banyumulek disesuaikan dengan bentuknya akan dikaji dari sudut pandang estetik dekoratif, ekonomi, pelestarian budaya serta fungsi dalam hubungannya dengan interior dan eksterior.

\section{Proses Pembuatan dan Pengolahan Bahan.}

Proses pembuatan gerabah Banyumulek merupakan suatu perjalanan berantai yang melewati beberapa fase atau tahapan demi tahapan sesuai dengan ketentuan yang telah diwarisi. Tahapan-tahapan tersebut antara lain, 
penentuan bahan baku, sistem pengolahan termasuk di dalamnya pembentukan, pembakaran, dekorasi dan penyelesaian (finising). Gustami Sp (1985) menyebutkan pola penggarapan kerajinan keramik adalah suatu mata rantai terjadinya produk kerajinan tersebut, mulai timbulnya inisiatif sebagai tanggung jawab kegiatan hingga pemasaran.

Tanah liat adalah bahan utama untuk pembuatan keramik atau gerabah, bahan ini cukup banyak dijumpai di berbagai wilayah Indonesia. Tanah liat yang terbentuk dari kristal-kristal kecil, dan mineral-mineral koalinit dan bila dicampur dengan air mempunyai sifat plastis (liat), mudah dibentuk. Dilihat dari sudut ilmu kimia menurut Ambar Astuti dalam Adirozal (1999), tanah liat termasuk dalam hidrosilikat alumina yang murni, mempunyai rumus $\mathrm{AL}_{2} \mathrm{O}_{3} 2 \mathrm{SiO}_{3} 2 \mathrm{H}_{2} \mathrm{O}$, dengan perbandingan berat unsurunsurnya $47 \%$ oksida silika $\left(\mathrm{SiO}_{2}\right), 39 \%$ oksida alumina $\left(\mathrm{AL}_{2} \mathrm{O}_{3}\right)$ dan $14 \%$ oksida air $\left(\mathrm{H}_{2} \mathrm{O}\right)$.

Bagan 2. Proses Pembuatan dan Pengolahan Bahan.

Secara umum tanah liat yang didapat di daerah Banyumulek tidak terlalu banyak mengandung bebatuan ataupun ranting akar semak rerumputan karen\# posisinya berada pada kedalaman hampir dua meter. Sebelum tanah liat tersebut mengalami proses pengolahan dengan teknik 
kering atau basah terlebih dahulu dikeringkan atau diawali dengan pemecahan dalam bentuk bongkahan-bongkahan (bakalan) kecil sehingga sinar matahari secara leluasa dapat meresap. Selanjutnya ditumbuk kembali serta memilih dengan membuang butiran--butiran kasar serta sisa-sisa kotoran akar kayu dengan cara mengayak dengan tujuan agar tidak menimbulkan rongga udara yang mengakibatkan keretakan pada waktu pembakaran.

Perendaman yang dilakukan 1 sampai 2 hari dalam kubangan lumpur dengan campuran air secukupnya dimaksudkan agar butiran-butiran partikel terkecil yang sangat halus menyatu kembali dan menjadi plastis. Dengan sifatnya plastis tanah liat akan mudah diolah dan dibentuk dalam berbagai ukuran seperti dipijit dengan tangan (pinching) berupa koil, digiling dalam bentuk lempengan (slab), dituangkan seperti cairan bahan cetak (casting) serta. ditempelkan (Zai, 1997:17). Kehalusan akan sifat bahan tanah liat tergambar pula dalam bentuk tesktur pada permukaan badan (body) gerabah sesuai dengan karakter alat yang digunakan dalam pembentukan.

Sifat-sifat fisik tanah liat dapat dikelompokkan misalnya, tanah liat tahan api, (fire clay), tanah liat tambang (ball clay), tanah liat bata merah (earthenware), dan tanah membatu (stoneware clay), masing-masing memiliki ciri dan daya plastis tersendiri. Sebagainya (Astuti 1997) Pengerajin Banyumulek mengolah bahan tanah liat dengan sistem kering dan basah disesuai dengan kondisi lingkungan yang terjadi. Hanya dengan cara menginjak-nginjak atau menumbuk dengan kayu serta menambahkan pasir secukupnya bisa menghasilkan adonan slap dibentuk, dilakukan secara serius dan kontinu, lewat perasaan (filling) atau meraba dengan tangan kebiasaan yang didapat secara turun temurun.. Selanjutnya disimpan beberapa hari dalam kantong plastik agar penguapan air tidak terlalu cepat dan tanah liat menjadi lebih lunak. Tanah liat yang baik diolah atau dibentuk adalah tanah liat yang sudah dibersihkan serta mengalami proses pemeraman dan pengawetan (Zai, Ibid).

Pembuatan gerabah dapat dilakukan dengan berbagai teknik misalnya teknik putar tangan (hand wheel), putar kaki (kick wheel), cetak tuang dan cetak tekan (Razak,1992). Apabila tanah liat sudah plastis bisa juga dibentuk dengan tangan (pinch) seperti dalam bentuk coil dan slab maupun diputar. Sejalan dengan itu proses pembuatan gerabah Banyumulek dapat dikolompokkan menjadi dua yaitu kelompok pengrajin yang menekuni teknik tradisional dan kelompok yang menerapkan teknologi semi tradisional (modern). Sebelum pembentukan dimulai terlebih dahulu diawali dengan penguletan tanah sampai rata (homogen) disesuaikan dengan besar kecilnya barang yang akan dibuat. Penguletan ini bertujuan untuk menghilangkan gelembung atau rongga-rongga udara dalam tanah, yang mengakibatkan keretakan pada waktu pembakaran. 
Beberapa pengrajin Banyumulek sudah memadukan tiknik pilin dan putar tangan yaitu dengan menaruh pilin-pilin diatas pelarik sederhana atau rembagan terbuat dari kayu berbentuk datar dan bundar. Setelah tanah tersebut berbentuk benda dalam kondisi setengah kering, bagian yang tidak rata dikerat lagi dengan pisau bengkok (pengkerikan), selanjutnya dikeringkan dengan angin dalam rentangan waktu kurang lebih 45 menit. Dalam kondisi gerabah setengah kering inilah penerapan dekorasi dengan teknik toreh dalam wujud garis sig-sag, lengkung, bidang giometris dengan kesan minimalis melambangkan kultur budaya Sasak.

Berkembangnya teknologi modern baik itu dalam proses pembentukan dan dekorasi membawa angin segar bagi kelompok pengrajin muda. Teknologi ini sangat diminati para pemula, mengingat dari proses awalnya lebih cepat dan praktis dalam menunjang kegiatan produksi. Misalnya teknik pembentukan dengan putar tangan dan kaki, teknik pendekorasian cetak tempel, dekorasi stempel, ukir, kombinasi kulit kerang dan anyaman rotan. Proses ini muncul berkat adanya kerja sama kelompok pengrajin dengan lembaga sosial masyarakat, maupun instansi terkait lainnya dalam hal pembinaan dan pelatihan terhadap para pengrajin muda di Banyumulek.

Namun demikian dalam pembentukan barang-barang gerabah variatif seperti motif fauna dan flaura yang banyak dimanfaatkan sebagai model gerabah Banyumulek tetap didukung dengan teknik kombinasi, penggabungan teknik (slab), pilin (coil), dan pijat tangan (pinch).

\section{Pembakaran}

Suatu rangkian terakhir dalam proses pembuatan gerabah adalah pembakaran, tahapan ini dilakukan untuk melepaskan sifat-sifat tanah liat yang mudah larut bila kena air. Pengrajin Banyumulek kebanyakan melakukan pembakaran pada alam terbuka lasimnya disebut tungku

Ladang dengan suhu yang tidak terlalu tinggi maksimal $1000 \mathrm{C}$, dalam tingkat pembakaran biskuit, sesuai dengan jenis dan sifat tanah liat (earthenware). Pembakaran dalam suhu rendah (biskuit) akan menghasilkan barang gerabah yang masih tembus air atau kadar peresapannya sangat tinggi. Pelaksanaan pembakaran biskuit pada umumnya memanfaatkan bahan bakar dari jerami, sekam maupun sabut kelapa baik itu gerabah tradisional maupun gerabah yang sudah mendapat sentuhan teknik modern. Namun gerabah dengan motif dekorasi beragam lebih banyak dibakar dalam tungku bak dengan bahan bakar dari ranting kayu untuk mendapatkan panas yang lebih merata (homogen).

\section{Bentuk dan Fungsi Gerabah Banyumulek}

Kerajinan gerabah Banyumulek yang berkembang sampai saat ini berjalan pada dua sisi sedikit berbeda dalam segi teknik. Satu sisi ada yang 
masih bertahan dengan sistem lama sedangkan dilain pihak beberapa pengrajin sudah memanfaatkan teknologi semi tradisional (modern). Kelompok ini berusaha menciptakan bentuk-bentuk gerabah variatif dan lebih berdaya guna yang ditunjang dengan dekorasi serta sedikit mencerminkan nilai-nilai individual yang kental. Perkembangan ini lebih banyak dimotori oleh pengrajin muda yang telah mendapatkan pendidikan ataupun pelatihan baik secara formal dan informal.

Namun kelompok pengrajin yang menerapkan teknologi semi tradisional (semi modern) tidak meninggalkan begitu saja model-model lama yang telah ada, melainkan berusaha terus mengembangkan baik dari segi desain dan fungsi yang disesuaikan dengan selera konsumen.

\section{Gerabah Tradisional dan Modern}

Seperti telah diuraikan sebelumnya bahwa kerajinan gerabah Banyumulek ada yang masih bertahan pada corak tradisional. Kerajinan ini tumbuh dan berkembang terutama pada kelompok pengrajin tua dengan pola-pola lama yang diwarisi dengan keterbatasan lahan dan persediaan bahan relatif sedikit, sehingga karya-karyanya pun dibuat cenderung untuk kegunaan dan nilai praktis (peralatan rumah tangga). Oleh karena model serta bentuk-bentuknya sangat monoton secara keseluruhan hampir sama dan mendekati bentuk silinder dengan mulut ke atas, gerabah-gerabah tersebut sangat sulit untuk diklasifikasikan secara mendetail. Misalnya : bentuk Periuk, Periuk air, Kendi basuh, Pasuh, Jeding, Kuali, dan Kendi maling, merupakan ciri khas gerabah Banyumulek bentuknya hampir sama dengan kendi upacara, ada badan, leher, dan kepala. Kendi maling ini dilengkapi dengan tutup yang menyatu pada kepala, sehingga pada saat menuangkan air dari corot kendi tersebut tutupnya tidak bisa lepas. Sesuai dengan namanya "kendi maling" saat mengisi air dari arah pantat dengan menjungkirbalikkan kendi yang bersangkutan.

Sedangkan bentuk-bentuk gerabah semi tradisional diproduksi oleh pengrajin muda yang memiliki keterampilan dan skil kreatif dalam menciptakan bentuk-bentuk baru berusaha mengawinkan nilai fungsi, struktur dan dekoratif disain sehingga menjadi lebih harmonis dan menarik.

Proses penciptaannya sedikit memasukkan unsur ungkapan serta rasa keindahan sesuai dengan imajinasi yang dialami. Pariasi bentuk benda hias, tidak menutup kemungkinan gerabah tersebut berkembang kebentuk gerabah ekspresi. Walaupun demikian bukan berarti gerabah modern dikatakan masuk dalam rumpun sent murni, melainkan tetap dalam posisinya dalam kelompok seni kriya (kerajinan ) dimana unsur kekriyaannya (hand crhaft) masih terliat sangat kental dibuat secara berulang-ulang dalam bentuk yang sama.

Kelompok pengrajin muda akhirnya memunculkan bentuk-bentuk patung gerabah, lampu taman, lampu ruangan tidur, lampu lilin gantung, pot 
gantung, bentuk guci dengan kombinasi standar dart metal. Demikian pula gerabah yang mengadopsi bentuk datar dengan teknik slab antara lain asbak, tempat lilin dengan pola bidang geomeris serta bentuk nare dengan aksen anyaman rotan pada bibir gerabah. Bentuk-gerabah asimetris lebih variatif dengan kandungan dekorasi sedikit lebih abstrak yang ditunjang dengan teknik kombinasi sehingga pemanfaatan unsur garis, bidang-bidang giometris, tekstur serta warna alami sebagai aksen dalam pendekorasian kelihatan lebih harmonis. Gerabah sebagai hasil kerajinan tangan bukan dalam bentuk benda pakai saja melainkan juga sebagai benda ekspresi perasaan terutama dalam hiasannya. Seni seperti ini dinamakan seni plastik dibuat penuh dengan ketrampilan, berbentuk tiga dimensional tidak sepenuhnya dipandang sebagai patung, sederhana dan kandungan simbolis tidak besar, menurut ukuran kebudayaan bersangkutan dikenal sebagai seni kerajian (Haviland 1999). Perkembangan gerabah semi tradisional hasil perkawinan antara kerajinan (seni kriya) dengan seni murni dapat memberikan dampak sangat positif terhadap pertumbuhan sosial ekonomi masyarakat Banyumulek.

\section{Unsur Garis}

Garis merupakan ikatan beberapa buah titik yang tergabung menjadi satu, berdimensi memanjang, pendek, vertikal, horizontal, lengkung, berombak, lurus dan seterusnya. Fadjar Sidik (1979). Seorang pengrajin berusaha menyusun garis pada bidang gerabah sebagai elemen untuk mendukung terbentuknya sebuah pola sesuai dengan penempatannya. Penerapan garis pada bagian permukaan gerabah dalam bentuk pola daun, batang, bunga dan buah untuk memberikan batasan ruang, gerak dan bentuk dari sebuah benda sehingga pola bentuk dapat memberikan arti sesungguhnya secara visual. Dalam pemilihan bentuk garis kebanyakan para pengrajin sadar akan potensinya, sehingga keefektifan garis yang tertuang secara maksimum dapat memberikan sugesti dan arti sesuai dengan keinginan. Hal ini dilakukan berdasarkan rencana hiasan (pradesain) lebih banyak menstranfer bentuk tumbuhan menjalar sehingga sulurnya yang digambar dengan gerakan melingkar-lingkar mengikuti pola susunan motif pada sebuah bidang.

Kesatuan garis juga tampak untuk memunculkan kekuatan bidang serta untuk membedakan bidang-bidang besar dan kecil. Intensitas garis yang berulang-ulang dalam bentuk melingkar atau spiral memberikan sugesti kelahiran (generative forces) pada pola hiasan yang mengambil motif pepatran atau stilirisasi tumbuh-tumbuhan menjalar, sehingga mengesankan bentuk garis yang padat. Dalam penggambaran motif lain di samping didominasi oleh garis lengkung juga banyak menggunakan bentuk garis lurus, lingkaran, segi empat dan segi tiga masing-masing memberikan pesan serta arti tersendiri. 
Bidang

Sebuah bidang akan lahir bila terjadi pemisahan antara bentuk atau motif yang satu dengan bentuk yang lain. Bidang dalam hal ini memiliki peranan yang sama seperti halnya garis dan bentuk. Walaupun demikian masih ada perbedaan yang sangat prinsipil, berkaitan dengan sifatnya yang nyata antara garis dan bidang terletak pada kekuatannya memberikan kesan illusi. Aming Prayitno (1979) menyebutkan selain bidang dalam bentuknya yang meruang mempunyai gerakan arah horizontal, diagonal, bergelombang, tegak lurus memiliki dimensi lebar dan dalam, dapat membantu kemungkinan dalam berbagai variasi seperti bulat, persegi, runcing, kubus dan sebagainya.

Dalam hubungannya dengan gerabah Banyumulek dijumpai beraneka macam bentuk bidang seperti bidang datar, bidang lengkung, bersudut, bidang bulat dan melebar. Pemanfaatan bidang dalam bentuk hiasan dapat mencerminkan sebuah keharmonisan antara struktur desain dengan dekoratif desain walaupun hanya goresan garis sebagai pembatas antara bidang yang satu dengan lainnya. Namun dengan cara pengulangan atau modifikasi bentuk yang variatif dapat mempengaruhi penglihatan serta menimbulkan kesan dinamis. Efek lain yang dapat ditimbulkan oleh bidang yang berdemensi dua atau bidang datar pada gerabah adalah kesan dominan dan monotun mengingat tampilannya hanya berkisar pada ukuran panjang dan lebar. Hal ini terkait dengan motif hiasan yang dimunculkan pada permukaan gerabah dengan cara mengoreskan garis baik secara bergelombang, spiral, lurus, segi tiga, dan garis tegak. Sebagai konsep awal karya gerabah yaitu kegunaan, para pengrajin berusaha menyempurnakan bentuk-bentuk bidang minimalis yang tetap mencerminkan estetika lewat garis-garis, tesktur yang muncul secara tidak sengaja dalam proses pembentukan.

Warna

Secara umum gerabah Banyumulek menampilkan warna merah kekuning-kuningan sebagai warna dasar alami yang diakibatkan oleh perubahan warna tanah setelah mengalami proses pembakaran. Oleh karena itu bentuk warna gerabah yang diinginkan tidak bisa ditentukan secara pasti seperti dalam membuat lukisan.

Sebagai elemen estetis khususnya dalam bentuk gerabah multi fungsi penerapan warna dapat membangkitkan perasaan serta kesegaran jiwa para penikmat. Pemilihan dan penerapan 
warna gerabah selalu dihubungkan dengan kegunaan berdasarkan suhu bakar yang diinginkan. Bentuk warna coklat kehitamhitaman lebih banyak digunakan untuk gentong penyimpan air, warna ini ditimbulkan pada posisi gerabah yang diletakkan paling dekat dengan pijaran lidah api waktu proses pembakaran. Warna merah tua yang memanfaatkan bahan daun asam serta warna merah menggunakan tanah pere.

Warna coklat hingga kehitam-hitaman melambangkan kejujuran, kebenaran dan harapan masa depan, artinya hasil kerajinan gerabah Banyumulek yang ditunjang dengan teknologi manual dikerjakan secara jujur, kebenaran dan tekun mampu memenuhi harapan masa. Pemanfaatan benda lain sebagai penunjang eksperimen dimasukanlah sedikit unsur putih dari kulit kerang, pasir laut, warna tembaga dari uang kepeng serta warna kuning kecoklat-coklatan dari bahan rotan.

\section{Fungsi Estetik Dekoratif}

Penciptaan seni telah ada sejak zaman prasejarah dan tumbuh pada setiap kelompok orang yang memiliki rasa keindahan. Pada dasarnya seni mempunyai nilai keberhargaan, keunggulan dan kebaikan sehingga sangat dibutuhkan oleh setiap insan manusia. Kualitas seni apabila dapat memenuhi kebutuhan dan keperluan manusia seni itu telah memenuhi kaidah-kaidah fungsi sesuai dengan yang diinginkan (Gie, 1996:47)

Gerabah yang dikenal sejak dahulu, bahkan diseluruh dunia menganggap hanya sebagai tempat atau wadah untuk menyimpan makanan apabila bentuknya tidak dapat mencenninkan nilai estetis. Nilai estetis dimaksud adalah nilai yang dipengaruhi oleh unsur kesenirupaan yang berlaku dalam lingkungan budaya setempat. Gerabah Banyumulek pada awalnya berfungsi sebagai alat upacara kemanusiaan seperti kelahiran, perkawinan dan kematian, disamping sebagai sarana kegiatan rumah tangga khususnya peralatan dapur. Mengamati kerajinan gerabah Banyumulek bukan berarti melihat wujud atau bentuknya secara realitas, namun berusaha mengamati secara saksama terhadap hakikat nilai seni yang terkandung dalam gerabah itu sendiri. Bastomi (1992) menyatakan bahwa pengamatan terhadap seni tidak terbatas pada penglihatan indrawi saja, namun juga penglihatan intuitif. Oleh karena itu wawasan dalam menilai sebuah karya seni di dalamnya termasuk kegiatan mengamati, mengetahui, cara pandang serta merasakan karya tersebut lewat panca indera. Demikian halnya dalam menilai karya gerabah Banyumulek yang dibuat secara bersamaan, proses penciptaan dan perkembangan bentuknya hampir merata pada setiap kelompok 
pengrajin. Penerapan unsur-unsur desain tidak sedikit yang saling tiru meniru sehingga melahirkan karya gerabah yang bernapaskan kebersamaan. Peranan Deperindag Nusa Tenggara Barat, investor New Zealand, P3SK Bali dalam pembinaan desain dan mutu kualitas bahan, menjadikan fungsi gerabah itu bergeser sedikit demi sedikit sesuai dengan permintaan dan perkembangan pasar. Fungsi estetik garabah dapat dijadikan sarana oleh pengrajin untuk menuangkan idenya, secara perlahan mulai melepaskan keterikatan pada bentuk gerabah dengan nilai guna.

Namun fenomena tersebut tidak membawa pengaruh yang berarti pada bentuk-bentuk gerabah tradisional yang berhubungan dengan kegiatan ritual kemanusian, karena keberadaannya sangat ditentukan oleh pakem-pakem yang jelas sesuai dengan ukuran tertentu. Periuk tempat ari-ari (plasenta), pasuh tempat memandikan bayi, paneh tempat air untuk memandikan mayat, maupun kendi tempat air basuh yang ditaruh di depan rumah tetap tumbuh mengikuti perjalanan modernisasi walapun dalam skala kecil.

Berkaitan dengan fungsi dan kegunaan berkembanglah bentuk-bentuk baru dengan membubuhi beberapa hiasan sebagai aksen keindahan untuk menunjang struktur gerabah itu sendiri. Perubahan dimaksud akhirnya melahirkan fungsi yang beraneka macam seperti gerabah sebagai elemen estetika taman, bentuk-bentuk patung, hiasan dinding lampu taman maupun tempat buah. Perubahan fungsi gerabah dengan membubuhi sedikit dekorasi atau dengan mengembangkan bentuk awalnya akan mengarah pada kreativitas dan memotivasi daya hayal para pengrajin dalam berkarya dan mencipta.

Penempatan pada ruang dalam (interior) difungsikan sebagai wadah, sedangkan pada ruang luar (eksterior) dimunculkan pada momen tertentu sebagai elemen estetika taman. Sistem pewarisan keterampilan dan keahlian yang dimiliki masyarakat Banyumulek akhirnya membentuk komunitas masyarakat industri yang menekuni bidang keahlian membuat gerabah secara profesional, dilandasi oleh keinginan kuat untuk meningkatkan kehidupan yang lebih baik dan bermakna.

\section{Fungsi Pelestarian Budaya}

Kerajinan gerabah Banyumulek berfungsi juga sebagai pelestarian budaya ditengah--tengah arus globalisasi antara budaya satu dengan lainnya. Mengingat kerajinan ini merupakan produk kesenian yang tumbuh dalam satu lingkaran budaya Banyumulek sudah memiliki kekuatan bentuk dan gaya sebagai jati diri sehingga faktor apapun yang datang mempengaruhi dapat diseleksi secara selektif.

Sebagai identitas atau jati diri budaya masyarakat Desa Banyumulek adalah hidup dalam kebersamaan dan berdampingan saling tolong menolong. Sikap kebersamaan sebagai jati diri dari nilai-nilai sosial kemasyarakatan, 
adat dan agama menyatu dalam kesatuan yang dilukiskan sebagai alat atau 'wadah' dalam bentuk gerabah. Hal ini diyakini dapat dijadikan pedoman dalam melangkah selanjutnya menuju masyarakat yang rukun dan damai. Bentuk dan hiasannya juga merupakan jati diri yang sering diwacanakan sebagai local genius. Konsep 'local genius' yang telah digariskan tetua mereka mampu bertahan terhadap pengaruh budaya luar, minimal dalam penyerapan pengaruh dapat mengintegerasikan unsur-unsur budaya luar kedalam budaya daerah sendiri.

\section{SIMPULAN}

Kerajinan gerabah Banyumulek merupakan bentuk kerajinan yang diwariskan secara turun temurun oleh nenek moyang dengan kelompok produksi gerabah tradisional yang ditunjang dengan peralatan dan sistem pembentukan sangat sederhana. Kedua produksi gerabah modern yang ditunjang dengan peralatan semi modern. dengan varian fungsi sesuai dengan bentuk yang telah direncanakan.

Fungsi estetik dekoratif muncul setelah gerabah dapat dijadikan sarana oleh pengrajin untuk menuangkan idenya dengan memadukan unsur garis, tekstur serta polesan warna kepermukaan bidang yang ekspresip. Kreativitas muncul diawali oleh pengaruh New Zealand dan P3SKP Bali dengan program pendidikan dan pelatihan tentang pengolahan bahan dan desain. Secara menyeluruh dapat dikatakan bahwa kerajinan gerabah merupakan produk budaya sebagai pengejawantahan nilai-nilai budaya setempat perlu dilestarikan dan dikembangkan sesuai dengan kemajuan ilmu dan teknologi

\section{DAFTAR RUJUKAN}

Adhyatman,S dan Abu Ridho, 1984. Tempayan Di Indonesia. Jakarta: Himpunan Keramik Indonesia.

1987. Kendi. Jakarta: Himpunan Keramik Indonesia.

Adirozal, 1999. "Usaha Gerabah Untuk Cendramata Dalam Pariwisata Sumatra Barat "(Tesis belum terbit). Denpasar: Universitas Udayana.

Alexsander Brian, 2001. Kamus Keramik. Jakarta: Melenia Populer.

Anwar, Wadjiz, 1985. Filsafat Estetika. Yogjakarta: Supersukses.

Ardika, I Wayan,2002. "Komponen Budaya Bali Sebagai Daya Tarik Wisata" makalah Seminar regional Pariwisata Budaya Berkelanjutan Suatu Refleksi dan harapan pada lustrurn VIII Universitas Udayana. Sabtu 14 September 2002, Denpasar

Astuti, Ambar, 1982. Teori Keramik I. Yogjakarta: Liberty.

Berger, Arthur Asa, 2000. Tanda-tanda Dalam Kebudayaan

Komtemporer. (terjemahan M Dwi Marianto)Yogjakarta:Tiara Wacana. 